\title{
Potenciál měření nesymbolických početních schopností pro časnou diagnostiku dyskalkulie
}

\author{
Vendula Šamajová, Hynek Cígler
}

\begin{abstract}
Abstrakt
Cílem studie je přispět k porozumění souvislostem mezi nesymbolickými numerickými schopnostmi a vývojovou dyskalkulií. Zabýváme se tedy početními funkcemi již na úrovni vrozených dispozic, předcházejících osvojení číselného aparátu, které jsou zajištovány instancí tzv. aproximativního numerického systému (ANS) a projevují se v dovednosti odhadu kvantit. Pokud tento vztah existuje, bylo by jej zřejmě možné využít pro praktickou diagnostiku dyskalkulie již v raném věku dítěte před projevením př́ípadných obtíží v numerických dovednostech. Naše pilotní studie srovnává úroveň nesymbolických početních schopností (početního odhadu) u dětí s dyskalkulií a kontrolní skupiny. Kompletní výzkumný soubor tvořilo 75 žákủ ve věkovém rozmezí 6,6 až 17,8 let $(\mathrm{M}=12,03$; $\mathrm{SD}=2,68)$, přičemž 25 (33\%) z nich vykazovalo matematické obtíže, které jsou v 17 príípadech $(23 \%)$ vysvětleny diagnózou dyskalkulie. Sběr dat byl realizován s využitím elektronického „testu početního odhadu“ vlastní konstrukce, tvořeného tzv. aproximativními úlohami založenými na principu diferenciace množství. Výsledky naznačují, že kontrolní skupina diskriminuje množství lépe než děti s matematickými obtížemi. Po kontrole věku respondentů je však vztah dyskalkulie a výkonu v testu početního odhadu slabý a statisticky nevýznamný, beta $=-0,232, \mathrm{p}=0,056$. Zjištěné výsledky jsou diskutovány ve vztahu k možnostem jejich využití v praxi.
\end{abstract}

Klíčová slova: nesymbolické numerické systémy, aproximativní numerický systém, ANS, diskriminace množství, diagnostika dyskalkulie

\section{POTENTIAL OF MEASURING NON-SYMBOLIC NUMERICAL ABILITIES FOR EARLY DIAGNOSIS OF DYSCALCULIA}

\begin{abstract}
The aim of the study is to contribute to the understanding of the links between non-symbolic numerical abilities and developmental dyscalculia. Therefore, we deal with the numerical functions already at the level of innate dispositions preceding the acquiring of numerical apparatus, which are ensured by the instance of the so-called approximate number system (ANS) and are manifested in the quantitative estimation skill. If the relationship exists, it might be possible to use it for the practical diagnosis of dyscalculia at an early age before showing any difficulties in numerical skills. Our pilot study compares the level of non-symbolic numerical abilities (counting) in children with dyscalculia and control groups. The complete research group consisted of 75 pupils aged between 6.6 and 17.8 years $(M=12.03$; $S D=2.68)$, with $25(33 \%)$ showing mathematical difficulties in 17 cases $(23 \%)$ explained by the diagnosis of dyscalculia. Data was collected using an electronic "numerical estimate test" of the own construction, constituted by the so-called approximation tasks based on the principle of differentiation of quantities. The results suggest that the control group discriminates the quantity better than children with mathematical difficulties. However, after checking the age of the respondents, the relationship between dyscalculia and numerical test output is weak and statistically insignificant, beta $=-0.232$, $p=0.056$. The results are discussed in relation to the possibilities of their use in practice.
\end{abstract}

Keywords: non-symbolic numerical systems, approximate number system, ANS, quantity discrimination, diagnostics of dyscalculia

Došlo: 27. 7. 2019

Schváleno: 17. 7. 2020 


\section{Úvod}

Ačkoli člověka charakterizuje schopnost symbolicky kódovat numerické informace, přinejmenším některé početní funkce mají biologickou bázi předcházející vlastnímu osvojení číselných symbolů. Již během minulého století byla empiricky prokázána existence vrozených numerických dispozic, nezávislých na lidském jazyce, které lze pozorovat naprríč celým ontogenetickým vývojem. Schopnost mentálních operací s množstvím byla pozorována od narození (Izard et al., 2009; Antell \& Keating, 1983) a podle novějších poznatků dokonce již v prenatálním období v posledním trimestru těhotenství (Schleger et al., 2014). Ve fylogenetickém měřítku jsou tyto psychické funkce sdílené napříč živočišnou řiší a slouží evolučnímu účelu zmapování kvantitativního aspektu prostředí (např. identifikace oblasti s potenciálně nejvyšším výnosem potravy i dalších zdrojů, největším počtem možných sexuálních partnerů či nejnižší přítomností konkurenčních predátorů (Agrillo, Piffer, \& Adriano, 2013; Taves, 1941; Kaufmann et al., 1949; Gelman \& Gallistel, 1978). Tento tzv. numerický smysl se od samotného počátku života evidentně vyvíjí a zpřesňuje (Xu \& Spelke, 2000), přičemž nejprve reaguje pouze na nesymbolické stimuly ve formě uskupení objektů a až později vytvárí spojení se symboly v podobě grafických číslic či verbálních číslovek (Dehaene, 2011). Ve shodě s tím představují Meck a Church (1983) tzv. preverbální početní mechanismus coby zdroj implicitních procesů, který zakládá rámec pro asimilaci symbolického systému a předurčuje exaktní počítání spočívající v manipulaci s naučenými symboly.

\section{Nesymbolické numerické systémy}

Zajištování popsaných preverbálních početních funkcí je připisováno instanci nesymbolických numerických systémů zodpovědných za dovednost diferenciace množství. Byly identifikovány dva př́slušné koncepty, z nichž první je označovaný jako „object tracking system“ (OTS), tedy systém pro sledování jednotlivých objektů, jež se v zahraniční literatuře běžně vyskytuje také pod pojmem "subitizing" (z lat. subitus, angl. sudden - náhlý, najednou, neočekávaně). Ten pracuje s malým množstvím prvků ( 2 až 3 u dětí, 2 až 4 u dospělých), které je schopný paralelně reprezentovat s relativně stabilní rychlostí i přesností (Cutini \& Bonato, 2012; Piazza, 2010). Druhý aparát umožňuje rozlišování většího počtu a nazývá se „approximate number system” (ANS). Existence OTS a ANS je do jisté míry disociovaná, ale nemůžeme mezi nimi vést jasnou hranici. S rostoucím věkem pak dochází ke zvyšování výkonnosti systémů a možná také prohlubování jejich specializace, která ve svém důsledku umožňuje selektivní zapojení OTS a ANS s ohledem na situaci (Agrillo et al., 2015). Dále vzhledem k tomu, že výkon aproximativního systému dokáže spíše než subitizing diferencovaně predikovat budoucí rozvoj symbolických matematických schopností, lze usuzovat na jejich těsnější spjatost s ANS ve srovnání s OTS (Anobile et al., 2016).

\section{Aproximativní numerický systém (ANS)}

Aproximativní (př́íp. aproximální) numerický systém (ANS) lze chápat jako přibližnou mentální reprezentaci počtu, která zajišt'uje rychlý a hrubý kvantitativní odhad. ANS vykazuje senzitivitu vůči tzv. rozsahu numerické vzdálenosti, tedy absolutnímu rozdílu mezi dvěma kontrastními množinami (Haist et al., 2015; Piazza et al., 2010). V praxi to např́iklad znamená, že jedinec dokáže na základě zběžného pohledu, respektive krátkého vystavení podnětu, odhadnout a porovnat množství dvou uskupení objektů, a určit tak početnější z nich. Funkční výhoda tohoto početního mechanismu tedy tkví především v rychlosti a relativní přesnosti zpracování stimulu v závislosti na velikosti množiny. Systém se přitom aktivuje při mohutnosti množin čítající 4 a více prvků, zatímco při nižších počtech je preferován systém OTS (Cutini \& Bonato, 2012; Sousa, 2010). 
Ukázalo se, že úroveň ANS se $\mathrm{v}$ průběhu ontogeneze vyvíjí, což se promítá ve zdokonalování jeho přesnosti, tedy schopnosti rozlišovat mezi uskupeními se stále menšími kvantitativními rozdíly (Lipton \& Spelke, 2004; Libertus \& Brannon, 2010). Vývojovou trajektorii funkce ANS, manifestující se zároveň jako specializace neuronální aktivity, reportovala průřezová studie Haista et al. (2015).

\section{Měření ANS}

ANS může být měřen úlohami komparace (diskriminace, diferenciace) množství, které zahrnují podnětový materiál v podobě shluků objektů, např. teček (Holloway \& Ansari, 2009). Na tomto základě vytvořené diskriminační testy zjišt'ují atribut správnosti a rychlosti odhadu, což vypovídá o tzv. ostrosti ANS, která je primárně určena relativním poměrem rozdílu v množství prvků a absolutní velikostí těchto kvantit (Chesney, 2018; Price et al., 2012). V praxi testování to znamená, že čím vyšší je poměrný rozdíl množství, tím snáze je ANS probandů dokáže rozlišit, přičemž s nižším množstvím se snižuje také rozdíl potřebný pro správnou diskriminaci. Jinými slovy, nižší kvantity, např. 4 a 6 (tj. v nižším poměru $2: 3)$, diferencujeme přesněji a rychleji než ty vyšší, např. 6 a 8 (tj. ve vyšším poměru 3:4) (Feigenson, Dehaene, \& Spelke, 2004; Agrillo et al., 2015; Cantrell et al., 2015; Coubart et al., 2015). Popsaný princip lze vyjádřit ve formě Weber-Fechnerova zákonu, který zachycuje lineární souvislost mezi změnou početnosti a schopností rozlišovat mezi dvěma kvantitami, a stává se tak měřítkem kapacity ANS (Xu \& Spelke, 2000). V této souvislosti byl také formulován tzv. efekt numerické vzdálenosti (NDE, event. NRE - numerical ratio effect) založený na inverzním vztahu mezi reakčním časem a velikosti rozdílu dvou komparovaných kvantit. Pro odlišení rozdílnějších četností tedy postačuje kratší čas než pro odlišení méně rozdílných (Holloway \& Ansari, 2009).

Nicméně validita a diferenciální potenciál Weberova zákona či NDE jako indikátoru funkce ANS jsou v současnosti polemizovány, vzhledem k tomu, že výsledky některých nedávných studií zpochybňují ideální lineární souvislost Weberovy konstanty, event. NDE, a ostrosti ANS (Holloway \& Ansari, 2009; Gilmore, Attridge, \& Inglis, 2011; Castronovo \& Goebel, 2012; Goebel et al., 2014; Price et al., 2012). Výsledky totiž ukazují na konstantní lineární vztah poměru a rozlišování množství u nižších rozmezí četností, avšak po překročení určité kritické hranice klesá schopnost diskriminace podle inverzní mocninné funkce (odmocniny). Na podkladě těchto zjištění navrhli Anobile, Cicchini a Burr (2014) existenci dvou modů zpracování, tj. jednoho pro určování množství následujícího konstantní mechanismus Weberova zákona a druhého pro identifikaci hustoty textury podléhajícího zákonitostem odmocnin (,square root law“). Z důvodu popsané inkonzistence a limitovanosti pojednávaných měřítek Chesney (2018) doporučuje, aby byla funkce ANS posuzována podle specifického koncepčního rámce daného podmínkami konkrétního př́ípadu („case-by-case basis“), kterými se rozumí zejména použitá metodika a distribuce ostrosti ANS v dané populaci.

\section{Neuronální báze ANS}

Z neuronálního hlediska je ANS spojován se specializovanými okruhy pro kódování množství, které patrně sídlí v prefrontálním a intraparietálním kortexu (Anderson \& Penner-Wilger, 2013; Nieder \& Miller, 2004). Jako centrální byla vymezena především oblast intraparietálního sulku (IPS), obklopená inferiorním (IPL) a superiorním (SPL) parietálním lalokem (Dehaene et al., 2003; Eger et al., 2003; Kadosh et al., 2008; Nieder, 2013), která prritom reflektuje interindividuální odlišnosti matematických kompetencí (Mussolin et al., 2010; Rotzer et al., 2008; Rykhlevskaia et al., 2009). Ve snaze o neuroanatomickou specializaci nesymbolického aspektu nicméně některé studie docházejí k závěru, že parietální centra se uplatňují spíše ve vztahu k číselným symbolům a souvisejícím aritmetickým operacím (Nieder, 2013; Pinel et 
al., 2001), zatímco prezentace nesymbolických objektů, relevantní konceptu ANS, vede kromě aktivace IPS (Piazza et al., 2004; Castelli, Glaser, \& Butterworth, 2006) k zapojení rovněž temporálně-okcipitálního kortexu (Cantlon et al., 2006; Izard et al., 2008; Nieder \& Dehaene, 2009).

Neurofyziologický princip aproximativního numerického kódování spočívá $\mathrm{v}$ tom, že všechny zapojené neurony jsou naladěny na preferovanou kvantitu (např. 4), ale aktivují se také při konfrontaci s podobným množstvím (např. 3, 5 či 6) (Kadosh, Lammertyn, \& Izard, 2008).

\section{Podstata fungování ANS}

Otázkou nadále zůstává úroveň neuronální báze procesů nesymbolického odhadu počtu (,nonsymbolical number estimation“), které zajišt'ují percepci, reprezentaci a determinaci množství prostřednictvím ANS. Jde o to, zda se tyto mechanismy vztahují již k senzorické funkci vizuálního aparátu, či zda probíhají až na stupni vyšších kognitivních mechanismů asociačních center zodpovědných za počítání (Anobile, Cicchini, \& Burr, 2015; Piazza et al., 2011). Některá výzkumná zjištění nasvědčují tomu, že fungování ANS spočívá již na úrovni neurálních struktur zodpovědných za vizuální kódování stimulů a intenci vizuální krátkodobé paměti („,visual-short term memory“ - VSTM), které dokáží generovat komplexní reprezentace vizuálního prostředí. Je např́íklad namítáno, že rozpětí subitizing (,subitizing range“) odráží limity VSTM, přičemž její kapacita odpovídá rozmezí $4 \pm 1$ položek (Cutini \& Bonato, 2012; Elmore et al., 2011). Podporu této myšlenky lze také spatřovat $\mathrm{v}$ následování principů Weberova zákona, který je atributem senzorických funkcí (Anobile, Cicchini, \& Burr, 2015), ačkoli lze namítnout, že vztah není ideálně lineární (Chesney, 2018). Dále senzorickému pojetí nasvědčuje, že vnímání počtu snadno podléhá adaptaci, stejně jako je tomu v př́ípadě percepce vizuálních atributů obrazu (barvy, kontrastu, velikosti, rychlosti) (Burr \& Ross, 2008). Avšak zatímco numericky selektivní neurony jsou aktivovány za předpokladu působení preferovaného podnětu, nikoli nutně nejčetnějšího, oblast zrakového kortexu V1 reaguje nejvýrazněji na nejvyšší počet (He et al., 2009; Harvey et al., 2013). To znamená, že na rozdíl od vizuální kůry, která odpovídá na množství energie, numericky selektivní populace neuronů následuje jinou instanci. Ve směru integrace představených zjištění pak přispívají některé zobrazovací studie, včetně jedné z českého prostředí (Plassová et al., 2016), které detekovaly dvě úrovně neurálního zpracování množství v závislosti na náročnosti úlohy (Piazza et al., 2010; Hyde, 2011). Ukázalo se, že podněty s nízkým rozsahem numerické vzdálenosti vedly k intenzivní aktivaci početního centra v intra-parietálním sulku (IPS), zatímco snadno rozlišitelné množiny stimulovaly ventrální oblast temporálního laloku, zodpovědnou za vizuální procesy.

\section{Vztah ANS a symbolických matematických schopností}

Nabízí se přirozeně otázka, jak se pojednávané presymbolické dispozice, zajištované funkcí aproximativního numerického systému (ANS), promítají do pozdějšího vývoje matematických kompetencí, uplatňujících se ve vztahu k tzv. exaktnímu numerickému systému (ENS) (Castronovo \& Goebel, 2012). Četné výzkumy zabývající se problematikou ANS ve vztahu k matematickým schopnostem skutečně pozorovaly jejich úzkou souvislost (Anobile et al., 2016; Chen \& Li, 2014; DeWind \& Brannon, 2012; Fazio, Bailey, Thompson, \& Siegler, 2014; Gilmore, McCarthy, \& Spelke, 2010; Haist et al., 2015; Halberda, Mazzoco \& Feigenson, 2008; Libertus et al., 2013; Libertus, Odic, \& Halberda, 2012; Schneider et al., 2016), ačkoliv existuje i řada studií s opačným závěrem (Chu, van Marle, \& Geary, 2015; Gilmore et al., 2013; Goebel et al., 2014; Iuculano et al., 2008; Lyons et al., 2014; Price et al., 2012; Sasanguie, Defever, Maertens, \& Reynvoet, 2014); Sullivan, Frank \& Barner, 2016). 
Vztah ANS a matematických schopností je zpravidla interpretovaný v tom smyslu, že aproximativní dispozice jsou prediktorem budoucího formálního výkonu a tedy i úspěchu v matematice (Gilmore, McCarthy, \& Spelke, 2010; Halberda et al., 2008; Purpura \& Logan, 2015; Starr, Libertus, \& Brannon, 2013; Soto-Calvo et al., 2015). Na tomto základě se nabízí pojetí ANS jako iniciačního neurokognitivního nástroje, prostřednictvím něhož se budují sofistikovanější aritmetické dovednosti (Piazza, 2010). Rovněž výsledky nedávných neuroimaginativních studií prokazují, že oba typy reprezentací vedly $\mathrm{k}$ aktivaci totožné neuronální substance, kterou je IPS (Bugden et al., 2012; Butterworth \& Walsh, 2011; Dehaene et al., 2003; Lussier \& Cantlon, 2016; Piazza et al., 2007; Sasanguie, Göbel, \& Reynvoet, 2013). $\mathrm{Na}$ druhou stranu se ukázalo, že nesymbolické numerické schopnosti jsou zpracovávány převážně pravou hemisférou, zatímco ty symbolické fungují spíše ve vztahu k levé části mozku, což implikuje základní rozdíl mezi nesymbolickými a symbolickými neurálními procesy (Ansari, 2007; Cantlon et al., 2006; Izard et al., 2008; Nieder \& Dehaene, 2009). Alternativní interpretaci předkládají van der Ven et al. (2016), eventuálně Haist et al. (2015), kteří vypozorovali, že v odpovědi na nesymbolické podněty se aktivují nervová centra vizuální představivosti, přičemž zpracování jednoduchých čísel zapojuje verbální pamět'. Pozoruhodný je dále př́nos Parka a Brannonové (2014), později Parka et al. (2016), kteří zjistili pozitivní efekt nácviku neverbálních presymbolických numerických dovedností na výkon $\mathrm{v}$ aritmetických testech. Tento efekt může být způsoben zvýšením konektivity neuronů v oblasti parietálního laloku, což by mohlo představovat velký potenciál pro prrípravu a podporu dětí v úspěšném studiu matematiky. S ohledem na to si lze dokonce i u nás již od počátku 21. století povšimnout trendu $\mathrm{v}$ didaktice matematiky spočívajícího $\mathrm{v}$ zavádění techniky nácviku matematického odhadu (Binterová \& Hošpesová, 2003; Binterová et al., 2005; Samková, 2013), který bývá ovšem často kombinovaný rovněž s úlohami zapojujícími i vyšší kognitivní funkce, s čímž se přirozeně pojí také komplexnější neurální aktivita.

Vzhledem k oběma protichůdným variantám výsledků se lze domnívat, že nesymbolické a symbolické matematické schopnosti mohou u dětí souviset $\mathrm{v}$ tom smyslu, že aproximativní numerický odhad může sloužit jako báze pro porozumění školské matematice, přičemž popsaný vztah slábne úměrně tomu, jak se formální aritmetické schopnosti stávají nezávislé na nesymbolickém základu a odkázané spíše na symbolické mechanismy. Kauzalitu lze společně s Feigensonovou (cit. dle Olmstead \& Kuhlmeier, 2015) deklarovat ve vztahu ke třem poznatkovým pilír̆um, zahrnujícím 1) individuální rozdíly ve funkci ANS vyskytující se již v dětství (Libertus \& Brannon, 2010), 2) přesnost ANS predikující v pozdějším vývoji matematický výkon (Mazzocco et al., 2011), 3) zlepšení formálních matematických schopností díky trénování ANS (Park \& Brannon, 2014; Park et al., 2016).

\section{Vývojová dyskalkulie}

Ve sféře deficitu matematických schopností se studie zaměřují na souvislost úrovně nesymbolických početních schopností a narušení symbolických matematických schopností, které tvoří podstatu vývojové dyskalkulie (Schwenk et al., 2017; Furman \& Rubinsten, 2012; Bugden \& Ansari, 2016; De Smedt et al., 2013). Dyskalkulie představuje specifickou vývojovou poruchu učení (SPU) v oblasti matematiky, která působí nejen narušení úspěšnosti školního výkonu, ale také profesního úspěchu i životní spokojenosti jedince, čímž může být poznamenáno jeho psychické i fyzické zdraví (Gross, Hudson, \& Price, 2009; Parsons \& Bynner, 2005). Z tohoto důvodu je zásadní podchytit záležitosti vyplývající z poruchy matematických schopností včas a nastavit žákovi takové podmínky, které respektují a umožňují rozvíjet jeho předpoklady (Novák, 2004).

Z hlediska etiologie dyskalkulie Desoete (2015) hovoří o narušeném „smyslu pro čísla“ spočívajícím ve schopnosti rychlého porozumění, odhadu a zacházení s číselnými veličinami. 
Butterworth (2010) se domnívá, že dyskalkulie může být výsledkem specifického deficitu reprezentace množiny prvků a manipulace s těmito výstupy v rámci aritmetických operací. Neurologické studie prokazují generalizovaný útlum center zodpovědných za reprezentaci počtu, tedy zejména ve fronto-parietálních oblastech mozku (Shalev et al., 2001; Kucian et al., 2006; Rotzer et al., 2009; Butterworth, Varma, \& Laurillard, 2011). V celkovém měř́tku pak dochází k narušení neurální konektivity mezi mozkovými oblastmi zapojenými v numerickém zpracování (Kucian et al., 2013; Rykhlevskaia et al., 2009). Na druhou stranu u dětí s dyskalkulií pozorujeme kompenzační mechanismy, které se projevují značnější závislostí na podpůrných mozkových funkcích souvisejících s pracovní pamětí, pozorností, monitorováním, aktualizováním či reprezentací pomocí prstů (Kaufmann et al., 2009; Kucian et al., 2011; Mussolin et al., 2010).

\section{Diagnostika dyskalkulie}

V praxi je předpokladem účinného protektivního působení pochopitelně časná identifikace dyskalkulie, která by měla zakládat na důkladné diagnostice vycházející z detailního posouzení matematických schopností. Je totiž klíčové, aby byl zajištěn včasný rozvoj matematických předpokladů, korespondující s tempem dozrávání centrální nervové soustavy, protože v opačném prrípadě stagnování vývoje bývá efektivnost korektivních opatření limitovaná (Novák, 2004; Kucian \& von Aster, 2014). Dủležitým výchozím krokem diagnostického procesu je přitom screening dyskalkulie, spočívající ve zmapování matematických schopností a detekci obtíží, vyžadujících další posouzení (Gliga \& Gliga, 2011). V jejím rámci jsou zjištovány základní schopnosti, které se osvědčily jako ukazatelé pozdějších matematických obtíží; např.: číst čísla, chápat stálost (konstantnost) množství, sčítat a srovnávat velikost jednomístných čísel (Mazzocco, 2005), odhadovat četnost (Geary et al., 2009) nebo počítat pozpátku či umístit počet v rámci analogové škály (Deloche et al., 1999). Nástroj př́mo určený pro screening dyskalkulie předkládá Butterworth (2003) v podobě testu „The Dyscalculia Screener", který pracuje právě s doménou rozlišování množství (numerozity), avšak vzhledem k zacházení s číslicemi a standardizací pro děti od 6 do 14 let se jeho záběr soustředí také až do školních let.

V souladu s popsaným diagnostickým potenciálem rozvíjeným $\mathrm{v}$ zahraničí se tato práce snaží poukázat na to, že je možné odhalit dyskalkulii nejen až později ve školním věku, kde bývá rozpoznána u žáků potýkajících se s číselnými počty či výpočty, ale potenciálně ohrožené děti by mohly být identifikovány $\mathrm{v}$ mnohem dřivějším okamžiku. U dětí předškolního věku je totiž možné určit specifické prekurzorové dovednosti, které fungují jako prediktory pozdějších matematických schopností (Aunio \& Niemivirta, 2010; Butterworth \& Laurillard, 2010). Ačkoliv v České republice existují testy určené k podrobné diagnostice dyskalkulie, např. DISMAS (Traspe \& Skalková, 2013), Neuropsychologická batéria testov na spracovávanie čísiel a počítanie u dětí (ZAREKI) (von Aster \& Weinholdová, 2008), Matematické předpoklady dětí v mladším školním věku (Novák, 2001, 2002) či Diagnostika matematických schopností a dovedností (Bednářová, 2015), screeningový test dosud chybí.

\section{Implikace ANS pro účel diagnostiky dyskalkulie}

Vzhledem k předpokládané souvislosti symbolického a nesymbolického aspektu početních schopností, respektive vztahu ANS k sémantické komponentě numerace, prokázané řadou výzkumů (např. Anobile et al., 2016; Bugden et al., 2012; Gilmore, McCarthy, \& Spelke, 2010; Halberda, Mazzoco, \& Feigenson, 2008; Park \& Brannon, 2014; Park et al., 2016; Piazza et al., 2007), se nabízí uvažovat také o spojitosti jejich dysfunkce. V souladu s touto logikou by se pak dyskalkulie jako deficit matematických schopností týkala také narušení nesymbolické báze. 
V případě, že by platil tento předpoklad existence užší souvislosti mezi preverbálními numerickými dispozicemi a př́tomností dyskalkulie, a to bez ohledu na směr př́padné kauzality, bylo by jej možné využít při diagnostice či screeningu dyskalkulie. Výhodou takového screeningu by byla možnost provádět jej ještě před osvojením symbolických numerických operací, a tedy ve velmi raném věku, což by uspíšilo zahájení prŕípadných kompenzačních opatření.

Řada studií skutečně prokázala u dětí s dyskalkulií přítomnost deficitu bazálních numerických schopností, vývojově předcházejících aritmetickým dovednostem a projevujících se ve vnímání a diferenciaci nesymbolických četností (von Aster \& Shalev, 2007; Butterworth, Varma, \& Laurillard, 2011; Geary, Bailey, \& Hoard, 2009; Landerl, Bevan, \& Butterworth, 2004; Desete et al., 2012; Mazzocco, Feigenson, \& Halberda, 2011; Landerl et al., 2009; Piazza et al., 2010; Pinheiro-Chagas et al., 2014; Olsson, Östergren, \& Träff, 2016), zatímco některé studie tento vztah nepotvrdily (Iuculano, Tang, Hall, \& Butterwoth, 2008; Rouselle \& Noël, 2007). Nabízí se možné vysvětlení vzhledem k odlišné povaze měřících nástrojů, v důsledku čehož může být dyskalkulie posuzována jednak na základě početní fluence (resp. rychlost prostého sčítání, odčítání, násobení jednomístných, event. dvoumístných čísel; Landerl, Bevan, \& Butterworth, 2004) a jednak komplexnějších matematických úloh (napřr. složitější počítání $\mathrm{s}$ vyššími čísly, prostorová představivost s využitím mentálních rotací, řešení matematických problémů ve formě slovních úloh; McLean \& Hitch, 1999). Důvodem nekonzistentních výsledků tedy může být strategie screeningu, přičemž způsob založený na početní fluenci vedl k potvrzení vztahu (Landerl, Bevan, \& Butterworth, 2004; Piazza et al., 2010), zatímco príístup využívající komplexnějších matematických výstupů nikoli (de Smedt \& Gilmore, 2011). De Smedt a Gilmore (2011) konkrétně zjistili, že děti s matematickými obtížemi se lišily od běžné populace $\mathrm{v}$ úlohách srovnávání symbolických numerických kvantit, avšak nikoli v př́ipadě komparace nesymbolických množin. Na druhou stranu novější studie autorů Olsson, Östergren a Träff (2016) vypovídá nejen o výraznějším narušení symbolické komponenty početních schopností u klinické skupiny, ale i nižší ostrosti ANS.

\section{Výzkumné předpoklady}

Ukázalo se, že v souvislosti s etiologií dyskalkulie je na místě usuzovat na deficit rovněž nesymbolického aspektu matematických schopností, čemuž nasvědčují výsledky převážné části výzkumů (Geary, Bailey, \& Hoard, 2009; Landerl, Bevan, \& Butterworth, 2004; Piazza et al., 2010; Furman \& Rubinsten, 2012), ačkoli se objevují rovněž konkurenční zjištění, obzvláště pak v případě mírnějších matematických obtíží (Iuculano et al., 2008; Rousselle \& Noël, 2007). V globálním měřítku tedy přetrvává nedostatečná probádanost preverbálních numerických schopností ve vztahu k dyskalkulii a nekonzistentnost výzkumných zjištění ohledně souvislosti těchto dvou proměnných (Schwenk et al., 2017). V praxi je pak její diagnostika zpravidla odsouvaná až do pozdějšího věku dítěte, což neumožňuje včasné plánování a započetí vhodných korektivních opatření. Ovšem za předpokladu potvrzení spojitosti nesymbolických matematických dispozic a dyskalkulie se nabízí řešení ve formě adaptace metod zjišt’ování dovednosti početního odhadu, coby potencionálního markeru numerické dysfunkce, pro účely časné diagnostiky dyskalkulie a prevence jejího dalšího rozvoje (Desoete, 2015).

\section{Výzkumný cíl a hypotézy}

Cílem této pilotní studie je zjistit úroveň nesymbolických početních schopností na základě měření dovednosti početního odhadu u dětí s dyskalkulií a konfrontace jejich výkonu s kontrolní skupinou. V této souvislosti stanovujeme hypotézu, že běžná populace bude podávat v testu početního odhadu významně lepší výkon než žáci s dyskalkulickými obtížemi, což vychází z výzkumných zjištění nižší úrovně nesymbolických početních dispozic u jedinců s poruchou 
matematických schopností (zejm. vývojovou dyskalkulií). Dále také prověříme, zda závisí výkon $\mathrm{v}$ testu početního odhadu na věku testovaného. Zde předpokládáme dosahování lepších výsledků staršími dětmi ve srovnání s mladšími, což vyplývá z poznatků o lepším početním odhadu u starších jedinců v důsledku zrání a formování nesymbolických početních schopností v průběhu ontogenetického vývoje, navíc paralelně provázeného jejich možným zdokonalováním při osvojování početních dovedností v rámci výuky matematiky.

\section{Výzkumný design}

První kroky naší výzkumné snahy směřovaly ke konstrukci výzkumného nástroje $\mathrm{v}$ podobě "testu početního odhadu" (TPO), spočívajícího v mechanismu diskriminace kvantit. Na další úrovni dochází k aplikaci vytvořené metody při měření dovednosti odhadu početnosti. Sběr dat probíhal záměrným př́ležitostným výběrem na základě administrace TPO školním dětem ve věku 6,6 až 17,8 let, v rámci běžné a klinické populace (s poruchou matematických schopností). Testové výstupy registrující správnost a reakční čas odpovědí, odpovídající přesnosti a rychlosti ANS, byly zpracovány prostřednictvím lineární regrese v SPSS v. 24.

\section{Výzkumný soubor}

Vzhledem k tomu, že dyskalkulie bývá diagnostikována až ve školním věku, byly za účelem zajištění určité homogenity výběrového souboru osloveny pouze školní děti, které jsou v různé míře s matematikou již konfrontovány. Výzkumný vzorek byl zajišt'ován převážně na základě záměrného př́ležitostného, př́íp. lavinového, výběru. Sběr dat probíhal v rámci kontextu institucionálního (PPP, dyscentrum, ZŠS, nemocnice) i soukromého (domácnost). S ohledem k výzkumnému designu dochází k rozlišení klinické a kontrolní skupiny, přičemž děti s poruchou matematických schopností byly testovány v rámci brněnské Pedagogicko-psychologické poradny - Akreditovaného pracoviště MŠMT, Základní školy Heyrovského a pražského Dyscentra, zatímco testování běžné populace probíhalo v prostředí Městské nemocnice Ostrava či domácností rodin dětí.

Kompletní výzkumný soubor sestává z 81 školních dětí, avšak s ohledem k heterogenní struktuře vzorku (zejm. jeho klinické části), komplikující následnou manipulaci s daty při analýzách a interpretaci výsledných zjištění, jsme se po delší úvaze rozhodli vymezit celkem 3 jeho kategorie. V první fázi jsme rozlišili skupinu kontrolní, zahrnující po vyřazení 6 nereprezentativních případů 50 žáků $(67 \%)$ bez vážnějších potíží v matematice či jiných oblastech, a klinickou, čítající celkem 25 dětí (33\%) potýkajících se podle výstupů vyšetření z PPP s nedostatky v matematice, př́padně dalšími přidruženými poruchami (zpravidla ADHD či jiné SPU). V návaznosti na to byl z klinického vzorku vydělen soubor dětí prímo s diagnostikovanou dyskalkulií, eventuálně s dyskalkulickými obtížemi, a vyloučeno 1 dítě s vážnější poruchou mentálních schopnosti, s výsledným počtem 17 (23 \% z celkového počtu validních př́ípadů).

Rozložení z hlediska pohlaví vypovídá o celkem rovnoměrném zastoupení dívek a chlapců $\mathrm{v}$ celkovém souboru, $\mathrm{v}$ mírný prospěch dívek (54\%). Totéž platí pro kontrolní a klinickou část skupiny, avšak u dětí s dyskalkulií je převaha dívek zásadnější (65\%). V souvislosti se strukturou věku dosahuje jeho střední hodnota v rámci kompletního vzorku přibližně 12 let, přičemž kontrolní skupina vykazuje mírně vyšší průměr $(\mathrm{M}=12,8 ; \mathrm{SD}=2,75)$ ve srovnání se skupinou klinickou $(\mathrm{M}=10,45 ; \mathrm{SD}=1,65)$ či dětí s dyskalkulií $(\mathrm{M}=10,72 ; \mathrm{SD}=1,6)$. 


\section{Měřící nástroj (,test početního odhadu“)}

Výzkumná metoda spočívá $\mathrm{v}$ elektronickém testu početního odhadu (TPO; na vyžádání dostupný u korespondenčního autora článku), tvořeného tzv. aproximativními úlohami (diskriminace množství), ve formě série vizuálních podnětů, které mají podobu dvou uskupení teček, tj. fixního (resp. s neměnným počtem teček) na pravé straně a variabilního (resp. s proměnlivým počtem teček; nižším či vyšším ve srovnání s fixním polem) na levé straně od středového fixačního bodu. Stimuly jsou prezentovány po dobu $300 \mathrm{~ms}$ a následné zaznamenání odpovědi reaguje na stisk klávesy „A“ či „L“, korespondující se stranou prezentace fyzicky většího stimulu. Test se skládá ze 4 subtestů (z nichž první je zácvikový) se zvyšující se obtížností, danou růstem množství položek (20-30-40-50) i kvantitou porovnávaných množin (10-10-15-25 objektů fixního pole). Výstupy testování zahrnují informace o vlastnosti položky (četnost proměnlivého pole/četnost fixního pole), správnosti (správně/špatně) a reakčním času (např. $0,95 \mathrm{~s}$ ).

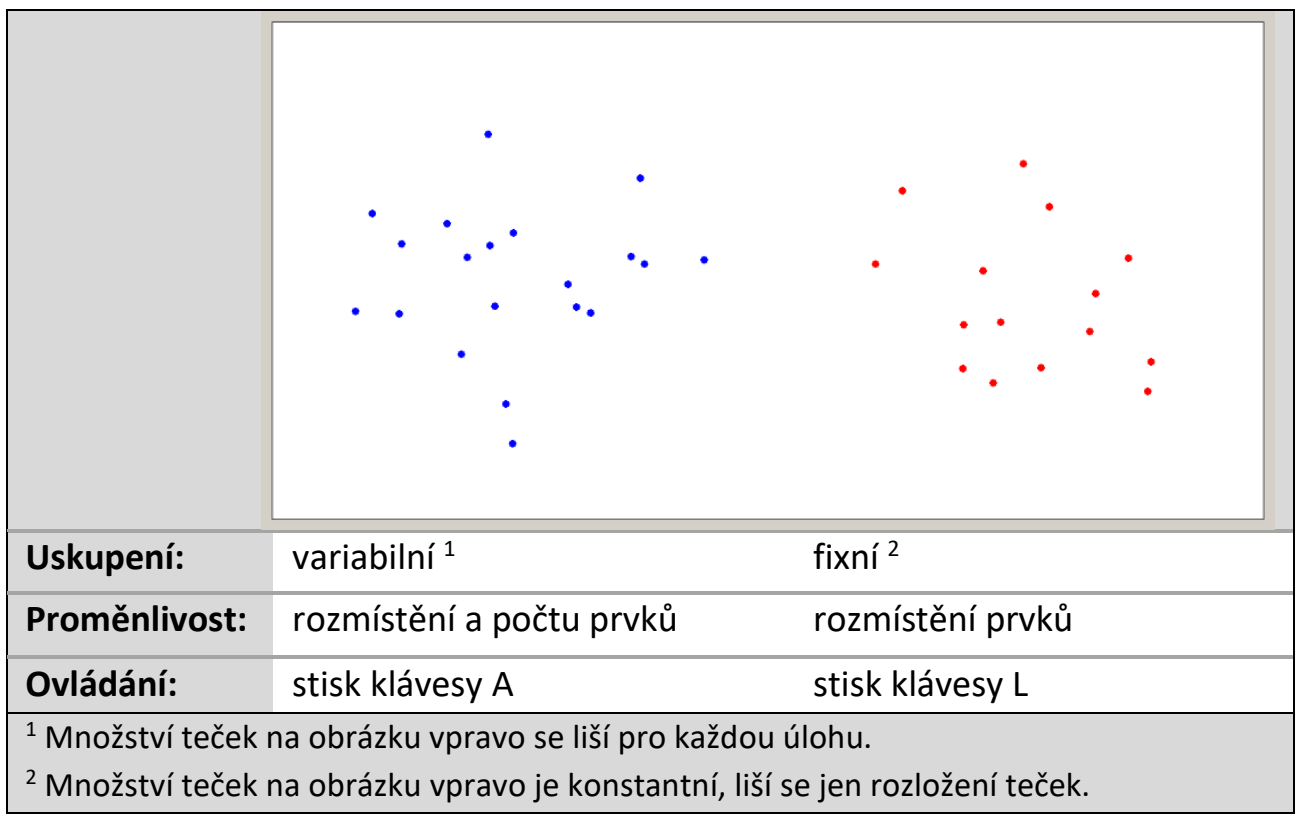

Obrázek 1 Podnětový materiál testu početního odhadu (TPO)

Test byl naprogramován s využitím platformy Matlab na základě stanovených parametrů. V prvé řadě se jednalo o specifikaci délky prezentace stimulu $(300 \mathrm{~ms})$, tedy bilanci na jednu stranu dolní časové hranice, aby mělo dítě šanci podnět zaznamenat, a na druhou stranu horní hranice, aby byly aktivovány pouze nesymbolické početní mechanismy.

Dále s ohledem na značné riziko chyby měření $\mathrm{z}$ důvodu vysoké pravděpodobnosti správného odhadu, vzhledem k př́tomnosti pouze jednoho distraktoru, bylo třeba za účelem dosažení dostatečné reliability zahrnout vysoký počet položek. Konkrétně Anobile et al. (2016) reportují na základě 45 úloh reliabilitu obdobné metody diferenciace kvantit $r=0,54$, přičemž Cígler (2018) s pomocí Spearmanova-Brownova vzorce odhaduje, že pro zajištění uspokojivé reliability celého testu $(\mathrm{r}=0,8)$ je nutné zařadit přibližně 153 položek paralelních k původním položkám Anobileho (2016) týmu. S přihlédnutím k limitům dětské mentální kapacity jsme se nakonec rozhodli administrovat celkově 140 položek, avšak s tím, že prvních 20 velmi 
snadných podnětů je určených zácviku, takže nejsou zahrnuty v celkovém skóru a nejsou ani použity pro ověřování psychometrických vlastností testu.

Rovněž jsme diskutovali nad rozvržením struktury testu, $v$ tom směru, aby bylo pro dítě jeho plnění pochopitelné, únosné a pokud možno i motivující. $Z$ toho důvodu byl test rozčleněn na 4 subtesty s narůstající obtížností, v důsledku zvyšování počtu položek a četnosti prvků fixního a tím i proměnlivého pole.

V souvislosti s obtížností podnětů pak byl zvažován minimální a maximální počet prvků proměnlivého pole ve vztahu $\mathrm{k}$ fixnímu, aby test neobsahoval př́liš banální položky postrádající schopnost diskriminace. Jako parametr spodní hranice byl zvolen poměr $1 / 3$ prvků proměnlivého pole ke stabilnímu a jeho horní limit byl stanoven na maximálně dvojnásobek fixního.

Za účelem zhodnocení položek testu z hlediska jejich obtížnosti a diskriminační účinnosti pak byla realizována položková analýza (korelace položek s celkovým skóre), jejímž prostřednictvím bylo identifikováno několik velmi snadných i náročných podnětů a zejména množství neuspokojivě rozlišujících. Důvodem může být pravděpodobně efekt "matoucího" rozmístění položek, který se přitom zdá být v rozporu s domněnkami o vnímání numerozity skrze hustotu textury (Durgin, 1995, 2008), vzhledem k tomu že množství pokryté plochy zůstává konstantní. Na druhou stranu však tento mechanismus vypovídá o roli jiných vizuálních fenoménů uplatňujících se při numerickém odhadu. Vnímaný efekt navíc může být odrazem pouze aproximativní citlivosti vizuálního aparátu, který nedokáže bez zapojení percepčních mechanismů vyšší úrovně rozlišit jednotlivé objekty v rámci koncentrovanějších shluků (Piazza et al., 2004). Na základě položkové analýzy byla tedy provedena selekce položek, jejímž výsledkem je soubor podnětů redukovaný z původních 120 (30-40-50) na finálních 85 (20-30$35)$, který disponuje vyšší reliabilitou (viz níže) a bude tedy využíván pro následné regresní analýzy.

Nakonec bylo také třeba stanovit repertoár výstupů, který bude test generovat. Test zachycuje odpovědi pro jednotlivé položky z hlediska jejich základních parametrů, tj. četnost podnětu, coby údaj o položce jako takové, a dále správnost i reakční čas, aby byly k dispozici základní i více diferencující ukazatele o dovednosti početního odhadu. Nicméně čas poskytuje v př́padě našeho výzkumu pouze doplňkovou informaci, protože účastníkům nebyla zadávána instrukce pracovat co nejrychleji.

S využitím metody vnitřní konzistence lze usuzovat na uspokojivou reliabilitu dílčích subtestů a vysokou úroveň spolehlivosti testu jako celku, která ještě vzrostla $\mathrm{v}$ důsledku vyřazení neuspokojivě měřících položek a pro celou redukovanou verzi testu ( 85 položek) dosahovala ve vztahu ke správnosti hladiny $\alpha=0,91$.

Tabulka 1: Ověření reliability ve vztahu ke správnosti $\left(\alpha_{s}\right)$ a reakčnímu času $\left(\alpha_{t}\right)(\mathrm{N}=81)$

\begin{tabular}{lrrr}
\hline (Sub)test & $\boldsymbol{\alpha}_{\text {s }}$ plné verze & $\boldsymbol{\alpha}_{\text {t }}$ plné verze & $\boldsymbol{\alpha}_{\text {s }}$ redukované verze \\
\hline 2. subtest & 0,69 & 0,95 & 0,74 \\
3. subtest & 0,78 & 0,96 & 0,82 \\
4. subtest & 0,74 & 0,97 & 0,83 \\
Celkový test & 0,87 & 0,99 & 0,91 \\
\hline
\end{tabular}


Rozdělení testu početního odhadu na více subtestů dále umožňuje posouzení spolehlivosti na základě jejich korelace navzájem a rovněž s celkovým testem.

Výsledky svědčí pro statisticky významné vztahy mezi subtesty, z nichž nejtěsněji spolu korelují 2 . a 3. subtest $(\mathrm{r}=0,698)$, a vysoké hladiny korelací jednotlivých subtestů s celým testem, zejména pak v prípadě 3 . subtestu $(\mathrm{r}=0,911)$.

Tabulka 2: Korelace subtestů redukované verze z hlediska správnosti $(\mathrm{N}=81)$

\begin{tabular}{lrrrr}
\hline & 2. subtest & 3. subtest & 4. subtest & Celkový test \\
\hline 2. subtest & 1 &, $698^{* *}$ &, $445^{* *}$ &, $762^{* *}$ \\
3. subtest &, $698^{* *}$ & 1 &, $661^{* *}$ &, $911^{* *}$ \\
4. subtest &, $445^{* *}$ &, $661^{* *}$ & 1 &, $878^{* *}$ \\
Celkový test &, $762^{* *}$ &, $911^{* *}$ &, $878^{* *}$ & 1
\end{tabular}

** Pearsonova korelace signifikantní na hladině 0.01

\section{Výsledky}

V následující tabulce jsou zachyceny hodnoty deskriptivní statistiky vypovídající o rozložení výkonu v TPO v rámci celkového souboru $(\mathrm{N}=81)$, pro jednotlivé subtesty (označené $1,2,3)$ i test jako celek. Nejprve je zobrazena struktura výsledků pro atribut správnosti (S) a následně reakčního času (T). Z prezentovaných dat je patrné, že probandi skórovali ve všech subtestech průměrně velmi vysoko při poměrně nízké odchylce. Nicméně jejich výkony se propastně lišily z hlediska rozpětí hodnot výsledných skórů, data tedy obsahovala značné množství odlehlých hodnot.

Tabulka 3: Výkon v TPO (pro 3 subtesty a celek) z hlediska správnosti (s) a reakčního času (t)

\begin{tabular}{lrrrrrrr}
\hline & N & M & SD & SE & Min & Max & Rozpětí \\
\hline S1 & 81 & 16,74 & 2,97 &, 330 & 3 & 20 & 17 \\
S2 & 81 & 24,99 & 4,46 &, 496 & 6 & 30 & 24 \\
S3 & 81 & 26,35 & 5,60 &, 623 & 12 & 34 & 22 \\
S & 81 & 68,07 & 11,24 & 1,250 & 37 & 83 & 46 \\
T1 & 81 & 32,90 & 11,64 & 1,29 & 7,44 & 60,01 & 52,57 \\
T2 & 81 & 38,93 & 13,76 & 1,53 & 11,32 & 78,15 & 66,83 \\
T3 & 81 & 46,29 & 18,37 & 2,04 & 11,26 & 104,54 & 93,28 \\
T & 81 & 118,12 & 40,59 & 4,51 & 33,72 & 220,74 & 187,02 \\
\hline
\end{tabular}

Tabulky č. 4 a 5 zachycují pro srovnání výsledky skupiny kontrolní a dětí s diagnózou dyskalkulie (event. dyskalkulických obtíží), z hlediska správnosti a času. Ve vztahu k nim pozorujeme určité odlišnosti výkonů, vždy ve prospěch dětí z kontrolního souboru. Touto optikou by se nabízelo usuzovat na tendenci k větší úspěšnosti početního odhadu u jedinců bez 
diagnózy dyskalkulie. Nicméně, jak již bylo předesláno při popisu výzkumného souboru, takováto premisa opomíjí aspekt věku, jehož vliv byl rovněž předpokládán.

Tabulka 4: Správnost v TPO (pro 3 subtesty a celek) u kontrolní skupiny a dětí s dyskalkulií

\begin{tabular}{lllllr}
\hline správnost & skupina & N & M & SD & SE \\
\hline S1 & kontrolní & 50 & 17,50 & 2,003 &, 283 \\
& dyskalkulie & 17 & 17,29 & 2,024 &, 491 \\
S2 & kontrolní & 50 & 26,72 & 2,241 &, 317 \\
& dyskalkulie & 17 & 24,00 & 4,950 & 1,200 \\
S3 & kontrolní & 50 & 28,40 & 4,121 &, 583 \\
& dyskalkulie & 17 & 24,18 & 6,812 & 1,652 \\
S & kontrolní & 50 & 72,62 & 7,102 & 1,004 \\
& dyskalkulie & 17 & 65,47 & 12,360 & 2,998 \\
\hline
\end{tabular}

Tabulka 5: Reakční čas v TPO (pro 3 subtesty a celek) u kontrolní skupiny a dětí s dyskalkulií

\begin{tabular}{llllll}
\hline čas & skupina & N & M & SD & SE \\
\hline T1 & kontrolní & 50 & 31,42 & 10,234 & 1,447 \\
& dyskalkulie & 17 & 36,97 & 10,489 & 2,544 \\
T2 & kontrolní & 50 & 37,00 & 10,652 & 1,507 \\
& dyskalkulie & 17 & 40,55 & 14,687 & 3,562 \\
T3 & kontrolní & 50 & 43,73 & 15,082 & 2,133 \\
& dyskalkulie & 17 & 50,81 & 21,179 & 5,137 \\
$\mathbf{T}$ & kontrolní & 50 & 112,15 & 33,867 & 4,790 \\
& dyskalkulie & 17 & 128,33 & 43,763 & 10,614 \\
\hline
\end{tabular}

Za účelem bližšího objasnění vztahu proměnných pak byla provedena metoda lineární regrese. Rovněž vzhledem k potencionálnímu vlivu věku, který navíc nebyl na úrovni sběru dat nijak striktněji regulován, byl v modelu lineární regrese kontrolován také tento věkový aspekt, pro který předpokládáme lineární vztah se stupněm měřených diskriminačních dovedností. Celkově jsme tedy zjišt’ovali, do jaké míry predikují nesymbolický numerický výkon faktory věku a dyskalkulie. Přitom jako ukazatel závislé proměnné byl vzhledem ke konzistentnosti testu zvolen pouze jeho celkový skór, a to z hlediska stěžejního kritéria správnosti (S). 
Tabulka 6: Lineární regrese výkonu v TPO pro faktor věku a dyskalkulie $(\mathrm{N}=75)$

\begin{tabular}{|c|c|c|c|c|c|c|}
\hline \multirow[b]{3}{*}{ konstanta } & \multicolumn{3}{|c|}{ model 1} & \multicolumn{3}{|c|}{ model 2} \\
\hline & B & beta & $\mathrm{p}$ & B & beta & $\mathrm{p}$ \\
\hline & 54,13 & & 0 & 58,86 & & 0 \\
\hline věk & 1,36 & 0,391 & 0,001 & 1,07 & 0,309 & 0,012 \\
\hline dyskalkulie & & & & $-4,87$ & $-0,232$ & 0,056 \\
\hline adj. $R^{2}$ & 0,153 & & & 0,200 & & \\
\hline $\mathbf{F}$ & $\mathrm{F}(1 ; 6$ & ,716, p & & $\mathrm{F}(2 ; 6$ & $3,002, p=$ & \\
\hline $\operatorname{adj.~deltaR}{ }^{2}$ & & & & 0,047 & & \\
\hline deltaF & & & & $\mathrm{F}(1,6$ & $, 785, p=$ & \\
\hline
\end{tabular}

Z předložené tabulky je patrné, že aspekt věku se uplatňuje jako statisticky významný prediktor úspěšnosti početního odhadu $(\beta=0,391 ; p=0,001)$, který vysvětluje $15,3 \%$ rozptylu celkového skóre. Následkem přidání proměnné dyskalkulie pak prediktivní potenciál věku mírně poklesl $(\beta=0,309)$, ovšem stále dosahuje hladiny signifikance $(p=0,012)$.

Zdá se nicméně, že samotný faktor dyskalkulie $\mathrm{k}$ predikci diskriminační dovednosti $\mathrm{v}$ zásadnější míř́ nepřispívá $(\beta=-0,232 ; p=0,056)$. Na základě zařazení aspektu dyskalkulie pak lze vzhledem $\mathrm{k}$ danému modelu objasnit varianci výkonu v TPO z celkem $20 \%$. V celkovém součtu jsou tedy sledované prediktory zodpovědné za objasnění méně než čtvrtiny celkového rozptylu výkonu v TPO. Vzhledem k popsaným výsledkům regresní analýzy tedy docházíme $\mathrm{k}$ závěru, že stanovený model lineární regrese, uvádějící nesymbolické početní schopnosti do vztahu s dyskalkulií a věkem, částečně přispívá k objasnění závislé proměnné, avšak nedokáže v zásadnější míře vysvětlit její komplexní charakter.

\section{Diskuze}

Realizovaná pilotní studie se zabývala problematikou nesymbolických početních schopností ve vztahu $\mathrm{k}$ dyskalkulii. Úroveň těchto preverbálních matematických předpokladů, která je připisována funkci kognitivního systému ANS, byla měřena prostřednictvím ,testu početního odhadu“ (TPO) vlastní konstrukce, inspirovaného metodikou využívanou za tímto účelem v zahraničních studiích. Nástroj tohoto typu založený na mechanismu diskriminace množství registroval správnost a reakční čas odpovědí, které by měly reflektovat přesnost a rychlost ANS. Test byl administrován skupině dětí s matematickými potížemi a kontrolní skupině a v návaznosti na to zjišt'ován možný vliv proměnných věku a obtíži dyskalkulického charakteru na úroveň nesymbolických numerických schopností, přičemž byl předpokládán jejich nižší stupeň u populace dětí mladších a s dyskalkulickými obtížemi. Informaci o úrovni nesymbolických početních schopností jsme usuzovali zejména na základě správnosti, která je stěžejním dokladem fungování ANS.

Zjištění vyplývající ze srovnání početního odhadu dětí s a bez matematických obtíží nasvědčují prítomnosti určitých rozdílů $\mathrm{v}$ jejich výkonu ve prospěch kontrolního vzorku, vzhledem $\mathrm{k}$ naměřeným průměrným hodnotám, a to ve vztahu ke správnosti i rychlosti odpovědí. Dokonce již v našich podmínkách přitom registrovala určité odlišnosti v percepci 
množství také jedna nedávno publikovaná diplomová práce (Pražáková, 2017) srovnávající výkon cílové a kontrolní skupiny v symbolických a nesymbolických úlohách, rovněž s využitím pro dané účely vytvořeného elektronického Testu vnímání množství. Na základě komparace průměrů reportuje práce signifikantní rozdíly $\mathrm{v}$ naměřených výkonech zejména $\mathrm{z}$ hlediska rychlosti odpovědí, čemuž nasvědčují i naše výsledky indikující delší reakční čas cílové skupiny. Bylo by tedy možné usuzovat také na pomalejší pracovní tempo vnímání množství $\mathrm{v}$ př́ípadě dětí s dyskalkulií. V kontextu zahraničních studií Mazzocco et al. (2011) prokázali, že dyskalkulici vykazovali výrazně sníženou kapacitu ANS ve srovnání s vrstevníky s normální úrovní matematických schopností. Dále Piazza et al. (2010) zjistili, že děti s dyskalkulií ve věku 10,7 let mají průměrně stejnou ostrost ANS jako běžné pětileté dítě. Rovněž aktuálnější studie prrináší důkaz, že žáci s matematickými obtížemi podávají horší výkon $\mathrm{v}$ nesymbolickém srovnávání i sčítání, dvou typech úloh zapojujících ANS (Pinheiro-Chagas et al., 2014).

Za účelem zohlednění faktoru věku pak bylo na výsledky nahlíženo z perspektivy lineární regrese, která ve vztahu ke stanoveným hypotézám prokázala určitou míru vlivu signifikantního prediktoru věku a nesignifikantního prediktoru dyskalkulických obtíži na výkon $\mathrm{v}$ testu početního odhadu. Nicméně vzhledem $\mathrm{k}$ jejich nízkému potenciálu přispět k vysvětlení celkového rozptylu $\left(\mathrm{R}^{2}=20 \%\right)$ se neukázal efekt jejich působení natolik zásadní, abychom je mohli označit za klíčové faktory úrovně nesymbolických početních schopností.

Z hlediska hlavní výzkumné hypotézy se tedy neprokázalo, že by atribut diagnózy dyskalkulie významněji predikoval výkon v úlohách diskriminace množství, což by nás pouze $\mathrm{s}$ přihlédnutím $\mathrm{k}$ výsledkům vedlo $\mathrm{k}$ interpretaci, že přítomnost dyskalkulie $\mathrm{s}$ funkcí ANS výrazněji nesouvisí. Z toho důvodu tedy není možné na základě dostupných zjištění jednoznačně potvrdit pro náš účel stěžejní předpokládanou souvislost nesymbolických početních schopností a dyskalkulie a nelze tak učinit ani v př́ípadě věku. Bylo by proto třeba uvažovat a analyzovat rovněž další významné prediktory dovedností numerického odhadu. Kromě toho si je nutné uvědomit, že byl zkoumán pouze lineární vztah proměnných, který nemůže sloužit jako doklad domnělé kauzální souvislosti, takže v tomto směru by bylo třeba se daným tématem blíže zabývat.

Ovšem nabízí se rovněž alternativní vysvětlení ve vztahu k limitům studie, se zřetelem na jejichž působení je třeba dosažené výsledky posuzovat. Nejzásadnější omezení platnosti našich zjištění plyne z podoby klinické skupiny, která vzhledem k problematické dostupnosti populace jednak čítala pouze malé množství prrípadů, a jednak vykazovala prŕliš heterogenní strukturu na to, aby se na jejím základě měl možnost projevit obecnější trend typický pro cílovou populaci. Jako zásadní otázka vystupuje předně také samotná platnost formálních diagnóz dyskalkulie, u nichž pochopitelně hrozí riziko záměny s jinými příčinami obtíží v matematice, čímž by mohl být efekt dyskalkulie rovněž zastíněn. Bylo by tedy potřeba se na úrovni dalšího výzkumu blíže zaměřit právě na tento aspekt a přispět také vlastním dílem k prověření potíží dyskalkulického charakteru prostřednictvím zařazení dalších standardizovaných metod, jako tomu zpravidla bývá v zahraničních studiích (Anobile et al., 2016; Landerl et al., 2009).

Z hlediska našeho výzkumného příspěvku je ovšem relevantní především aspekt závislé proměnné nesymbolických početních schopností, jejichž zjišt’ování spočívá v měření fungování za ně odpovědné instance aproximativního numerického systému. V této souvislosti pak je třeba důkladněji diskutovat konstruktovou validitu našeho měřícího nástroje, ve formě testu početního odhadu, reflektující jeho schopnost měřit výkon v rozmezí skutečně daném funkcí aproximálního smyslu, nikoli jinými kognitivními dispozicemi. Ve vztahu ke kapacitě ANS se totiž nelze spokojit pouze $\mathrm{s}$ vymezením jeho spodní hranice přecházející $\mathrm{v}$ mechanismus subitizing, ale je potřeba se hlouběji zamyslet rovněž nad limity vymezujícími jeho maximální potenciál. $Z$ evoluční perspektivy může podle našeho mínění odrážet popsaný princip skutečnost, že rovněž v reálném životě je pro člověka od určitého hraničního momentu další 
navyšování množství irelevantní, protože nám už nepřináší další přidanou hodnotu. Navíc mírné kvantitativní výkyvy nelze považovat za dostatečně vypovídající informaci, protože se mohou rychle měnit vlivem kvalitativních atributů okolních podmínek. Je tedy možné, že pásmo diferenciace kvantit, ve kterém se uplatňuje čistě ANS, je relativně úzké a nejsou tudíž v jeho rámci přítomny natolik markantní interindividuální rozdíly, aby samo o sobě skýtalo tak značnou diferenciační hodnotu. Rovněž evoluční optikou se může jevit smysluplné, aby všichni jedinci disponovali potřebnou úrovní diskriminační dovednosti a byli tak schopni zmapovat okolní terén sami za sebe či přispět k jeho prozkoumání v rámci komunity.

$\mathrm{Na}$ základě konfrontace vyjádřených úvah s našimi výzkumnými zjištěními, v podobě výstupů $\mathrm{z}$ testu početního odhadu, lze uvažovat o modelu dvouúrovňového zpracování diskriminace množství. Pokud je rozdíl zjevnější, uplatňovala by se vizuální funkce zapojující vizuální mozková centra, sehrávající evoluční a ontogenetický význam. Její rozložení v populaci přitom ze své podstaty nevykazuje markantnější interindividuální odlišnosti a neukrývá proto tak slibný diferenciační potenciál. V případě, že je rozdíl méně patrný, tedy evolučně irelevantní, participovaly by na zpracování kvantit rovněž kognitivní procesy, zajišstované neurálními oblastmi specializujícími se na početní operace. Naznačený princip navíc koresponduje s nálezy některých zobrazovacích studií, které registrovaly dvě úrovně neurálního zpracování množství v závislosti na náročnosti úlohy, takže srovnávání numericky podobných množin se projevovalo intenzivní aktivací numerického centra $\mathrm{v}$ intraparietálním sulku, zatímco snadno diferencovatelné četnosti aktivovaly ventrální oblast temporálního laloku, která se uplatňuje ve vztahu k vizuálním procesům (Plassová et al., 2016; Piazza et al., 2010; Hyde, 2011). Na kognitivní úrovni se navíc vytváŕí prostor pro zapojení rovněž nenumerických poznávacích funkcí, včetně pozornosti, pracovní paměti, myšlení či učení, i dalších psychologických faktorů, jako naprríklad motivace, důslednosti, snahy uspět a prŕípadně i negativního mentálního rozpoložení, spojeného s nervozitou či úzkostností. Tyto intelektové, kognitivní a výkonové předpoklady i další spolupodílející se psychické procesy, jejichž rozložení $\mathrm{v}$ populaci je výrazně interindividuální a navíc ovlivnitelné tréninkem, se pravděpodobně měly šanci při výkonu $\mathrm{v}$ testu projevit a mohly tak zastínit reálné narušení aproximativního numerického systému u dětí s dyskalkulií.

Př́islib praktického využití našeho výzkumného př́spěvku tedy zakládá na předpokladu implementace dílčích úprav testu početního odhadu a následného prokázání jeho měřících schopností na rozsáhlejším výzkumném souboru, aby tento nástroj mohl být použitelný jako součást screeningu narušení matematických schopností. Jako silná stránka metody se ukázala být její dostatečně vysoká reliabilita, zjištěná i pro jednotlivé subtesty, která ještě vzrostla $\mathrm{v}$ důsledku vyřazení neuspokojivě měřících položek a pro celou redukovanou verzi testu (85 položek) dosahovala hladiny $r=0,91$, což výrazně převyšuje reliabilitu reportovanou Anobilem et al. (2016) pro set 45 diskriminačních úloh $(\mathrm{r}=0,54)$. Neoddiskutovatelnou výhodou metody založené na diskriminaci množin je totiž její časová úspornost a rovněž relativně nízké nároky na administraci díky jednoduchému principu a jednotným instrukcím, takže může být snadno zařaditelná do širšího kontextu vyšetření. Zejména dobu testování (samotné plnění 120 úloh trvá průměrně cca 2 minuty, celková administrace přibližně 5 minut) lze pokládat za velmi př́iznivou a tedy pravděpodobně nezatěžující natolik mentální kapacitu dítěte. Ve prospěch elektronických testů navíc vypovídá myšlenka, že administrace skrze počítač je pro děti atraktivní a zejména oproštěná od sociálního tlaku působícího úzkost (Kucian \& von Aster, 2015). Př́větivým a poutavým podáním administrace metod tohoto typu tak můžeme dosáhnout nenuceného i zábavného způsobu podrobení se měření početních schopností, a to i u žáků, kteří zaujímají vůči školní matematice negativní postoj, což je zpravidla právě př́ípad dětí s deficitem v matematických schopnostech. 


\section{Závěr}

Ve světle empirických zjištění prezentovaných $\mathrm{v}$ teoretickém úvodu $\mathrm{v}$ konfrontaci $\mathrm{s}$ interpretacemi, které vyplývají z reportovaných výzkumných výsledků, a s ohledem k limitům měřícího nástroje zůstává nadále otázkou, zda dyskalkulie skutečně souvisí s narušením také presymbolického aspektu početních funkcí. Lze se totiž domnívat, že oslabená funkce nesymbolického numerického systému ANS je faktorem spolupodílejícím se na vzniku dyskalkulie prostřednictvím narušení rozvoje matematických schopností. Je ovšem třeba optimalizovat metody určené $\mathrm{k}$ měření tohoto neverbálního aspektu tak, aby poskytovaly validní informaci o úrovni fungování aproximativního systému a tedy skutečně odrážely nesymbolickou komponentu numerických předpokladů.

Praktickým posláním této studie bylo poukázat na to, že existuje potenciál pro odhalení dyskalkulie nejen až později ve školním věku, kdy bývá rozpoznána u žáků potýkajících se $\mathrm{s}$ číselnými počty a výpočty, ale ohrožené děti by mohly být identifikovány $\mathrm{v}$ mnohem dřivějším okamžiku. U dětí předškolního věku je totiž možné určit specifické prekurzorové dovednosti, např́klad právě presymbolické numerické dispozice, které fungují jako prediktory pozdějších matematických schopností, což může být zužitkováno $\mathrm{v}$ oblasti vývoje diagnostických, respektive screeningových nástrojů pro časnou identifikaci dyskalkulie díky zacházení s úlohami nesymbolické povahy. Taková praxe by pak ve svém důsledku umožnila včasné nastavení a započetí facilitačních opatření už v momentech dětského vývoje, jež jsou vzhledem ke zrání centrální nervové soustavy kritická pro rozvoj numerických dispozic podmiňujících následné formování aritmetických dovedností. Námi navržená metoda dosahuje při časově nenáročné administraci velmi uspokojivé reliability, jakkoliv zatím není jasné, jaká je její validita vůči předpokládanému použití při screeningu dyskalkulie.

\section{Poděkování}

Rádi bychom poděkovali doc. Lence Lacinové za její užitečné podněty, nápomocné při finálních úpravách př́spěvku.

\section{Literatura}

Agrillo, C., Petrazzini, M. E. M., \& Bisazza, A. (2015). At the root of math: Numerical abilities in fish. In D. C. Geary, D. B. Berch, \& K. Mann Koepke (Eds.), Evolutionary origins and early development of number processing (Vol. 1, Mathematical cognition and learning, pp. 3-33). San Diego, CA: Elsevier Academic.

Aunio, P., \& Niemivirta, M. (2010). Predicting children's mathematical performance in grade one by early numeracy. Learning and Individual Differences, 20, 427-435. https://doi.org/10.1016/j.lindif.2010.06.003

Anderson, M. L., \& Penner-Wilger, M. (2013). The relation between finger gnosis and mathematical ability: why redeployment of neural circuits best explains the finding. Frontiers in Psychology, 4, 877 11. https://doi.org/10.3389/fpsyg.2013.00877

Anobile, G., Castaldi, E., Turi, M., Tinelli, F., \& Burr, D. C. (2016). Numerosity but not texture density discrimination correlates with math ability in children. Developmental Psychology, 52(8), 1206-1216. https://doi.org/10.1037/dev0000155

Anobile, G., Cicchini, G. M., \& Burr, D. C. (2015). Number as a primary perceptual attribute: a review. Perception, 45, 5-31. https://doi.org/10.1177/0301006615602599

Ansari, D. (2007). Does the parietal cortex distinguish between "10," "ten," and ten dots? Neuron, 53(2), 165-167. https://doi.org/10.1016/j.neuron.2007.01.001 
Antell, S. E., \& Keating, D. P. (1983). Perception of numerical invariance in neonates. Child Development, 54(3), 695-701. https://doi.org/10.2307/1130057

Bednářová, J. (2015). Diagnostika matematických schopností a dovedností. Brno: Pedagogickopsychologická poradna Brno.

Binterová, H., \& Hošpesová, A. (2003). Objevování v matematickém vyučování podporované Excelem. University of South Bohemia České Budějovice Department of Mathematics Report Series 11, 267-273.

Binterová, H., Milota, J., \& Vaníček, J. (2005). Global School - virtuální prostředí pro výuku matematiky na ZŠ formou e-learningu. University of South Bohemia České Budějovice Department of Mathematics Report Series, 13.

Bugden, S. \& Ansari, D. (2016). Probing the nature of deficits in the 'Approximate Number System' in children with persistent developmental dyscalculia. Developmental Science, 19, 817-33. https://doi.org/10.1111/desc. 12324

Bugden, S., Price, G. R., McLean, D. A., \& Ansari, D. (2012). The role of the left intraparietal sulcus in the relationship between symbolic number processing and children's arithmetic competence. Developmental Cognitive Neuroscience, 2, 448-457. https://doi.org/10.1016/j.dcn.2012.04.001

Burr, D., \& Ross, J. (2008). A visual sense of number. Current Biology, 18, 425-428. https://doi.org/10.1016/j.cub.2008.02.052

Butterworth, B. (2003). Dyscalculia Screener. London: nferNelson. Dostupné z: http://www.dyscalculie.com/dlbin/dyscalculia_screener_manual.pdf

Butterworth, B. (2010). Foundational numerical capacities and the origins of dyscalculia. Trends in Cognitive Sciences, 14(12), 534-541. https://doi.org/10.1016/j.tics.2010.09.007

Butterworth, B., \& Laurillard, D. (2010). Low numeracy and dyscalculia: identification and intervention. ZDM Mathematics Education, 42, 527-539. https://doi.org/10.1007/s11858-0100267-4

Butterworth, B., Varma, S., \& Laurillard, D. (2011). Dyscalculia: From brain to education. Science, 27(6033), 1049-1053. https://doi.org/10.1126/science.1201536

Butterworth, B. \& Walsh, V. (2011). Neural basis of mathematical cognition. Current Biology, 21, 1337-1420. https://doi.org/10.1016/j.cub.2011.07.005

Cantlon, J. F., Brannon, E. M., Carter, E. J., \& Pelphrey, K. A. (2006). Functional imaging of numerical processing in adults and 4-y-old children. PLoS Biology, 4(5), e125. https://doi.org/10.1371/journal.pbio.0040125

Cantrell, L., Boyer, T. W., Cordes, S., \& Smith, L. B. (2015). Signal clarity: An account of variability in infant quantity discrimination tasks. Developmental Science, 18, 877-893. https://doi.org/10.1111/desc. 12283

Chesney, D. (2018). Numerical distance effect size is a poor metric of approximate number system acuity. Attention, Perception, \& Psychophysic, 80, 1057-1063. https://doi.org/10.3758/s13414$018-1515-\mathrm{x}$

Cígler, H. (2018). Matematické schopnosti : teoretický přehled a jejich měření. Brno: Masarykova univerzita.

Chu, F. W., van Marle, K., \& Geary, D. C. (2015). Early numerical foundations of young children's mathematical development. Journal of Experimental Child Psychology, 132, $205-212$. https://doi.org/10.1016/j.jecp.2015.01.006

Castelli, F., Glaser, D. E., \& Butterworth, B. (2006). Discrete and analogue quantity processing in the parietal lobe: a functional MRI study. Proceeding of the National Academy of Sciences of the USA, 103, 4693-4698. https://doi.org/10.1073/pnas.0600444103

Castronovo, J., \& Göbel, S. M. (2012). Impact of high mathematics education on the number sense. Plos One, 7(4), 1-16. https://doi.org/10.1371/journal.pone.0033832

Coubart, A., Streri, A., de Hevia, M. D., \& Izard, V. (2015). Crossmodal discrimination of 2 vs. 4 objects across touch and vision in 5-month-old infants. PLoS One, 10(3), e0120868. https://doi.org/10.1371/journal.pone.0120868

Cutini, S., \& Bonato, M. (2012). Subitizing and visual short-term memory in human and non-human species: a common shared system? Frontiers in Psychology, 3, 469.

https://doi.org/10.3389/fpsyg.2012.00469 
Dehaene, S. (2011). The number sense: How the mind creates mathematics (2nd ed.). New York: Oxford University Press.

Deloche, G., Souza, L., Braga, L. W., \& Dellatolas, G. (1999). A calculation and number processing battery for clinical application in illiterates and semi-literates. Cortex, 35, 503-521. https://doi.org/10.1016/S0010-9452(08)70815-3

Desoete, A. (2015). Predictive indicators for mathematical learning disabilities/dyscalculia in kindergarten children (pp 90-100). In S. Chinn (Ed.), The International handbook for mathematical difficulties and dyscalculia. London \& New York: Routledge.

De Smedt, B., Gilmore, C. K. (2011). Defective number module or impaired access? Numerical magnitude processing in first graders with mathematical difficulties. Journal of Experimental Child Psychology, 108, 278-292. https://doi.org/10.1016/j.jecp.2010.09.003

De Smedt, B., Noël, M. P., Gilmore, C., \& Ansari, D. (2013). How do symbolic and non-symbolic numerical magnitude processing skills relate to individual differences in children's mathematical skills? A review of evidence from brain and behaviour. Trends in Neuroscience and Education, 2(2), 48-55. https://doi.org/10.1016/j.tine.2013.06.001

DeWind, N. K., \& Brannon, E. M. (2012). Malleability of the approximate number system: effects of feedback and training. Frontiers in Human Neuroscience, 6, 68. https://doi.org/10.3389/fnhum.2012.00068

Durgin, F. H. (1995). Texture density adaptation and the perceived numerosity and distribution of texture. Journal of Experimental Psychology-Human Perception and Performance, 21, 149-169. https://doi.org/10.1037/0096-1523.21.1.149

Durgin, F. H. (2008). Texture density adaptation and visual number revisited. Current Biology, 18, R855-R856. https://doi.org/10.1016/j.cub.2008.07.053

Elmore, L. C., Ma, W. J., Magnotti, J. F., Leising, K. J., Passaro, A. D., Katz, J. S., Wright, A. A. (2011). Visual short-term memory compared in rhesus monkeys and humans. Current Biology, 21, 975-979. https://doi.org/10.1016/j.cub.2011.04.031

Fazio, L. K., Bailey, D. H., Thompson, C. A., \& Siegler, R. S. (2014). Relations of different types of numerical magnitude representations to each other and to mathematics achievement. Journal of Experimental Child Psychology, 123, 53-72. https://doi.org/10.1016/j.jecp.2014.01.013

Feigenson, L., Dehaene S., \& Spelke, E. (2004). Core systems of number. Trends in Cognitive Science, 8, 307-314. https://doi.org/10.1016/j.tics.2004.05.002

Furman, T., \& Rubinsten, O. (2012). Symbolic and non-symbolic numerical representation in adults with and without developmental dyscalculia. Behavioral \& Brain Functions, 8(1), 55-69. https://doi.org/10.1186/1744-9081-8-55

Geary, D. C., Bailey, D. H., \& Hoard, M. K. (2009). Predicting mathematical achievement and mathematical learning disability with a simple screening tool the number sets test. Journal of Psychoeducational Assessment, 27(3), 265-279. https://doi.org/10.1177/0734282908330592

Gelman, R., \& Gallistel, C. R. (1978). The child's understanding of number. Cambridge, MA: Harvard University Press.

Gilmore, C., Attridge, N., \& Inglis, M. (2011). Measuring the approximate number system. The Quarterly Journal of Experimental Psychology, 64, 2009-2109. https://doi.org/10.1080/17470218.2011.574710

Gilmore, C. K., McCarthy, S. E., \& Spelke, E. S. (2010). Non-symbolic arithmetic abilities and mathematics achievement in the first year of formal schooling. Cognition, 115, 394-406. https://doi.org/10.1016/j.cognition.2010.02.002

Gliga, F., \& Gliga, T. (2012). Romanian screening instrument for dyscalculia. Procedia-Social and. Behavioral Sciences, 33, 15-19. https://doi.org/10.1016/j.sbspro.2012.01.074

Goebel, S. M., Watson, S. E., Lervag, A., \& Hulme, C., (2014). Children's arithmetic development it is number knowledge, not the approximate number sense, that counts. Psychological Science, 25 (3), pp. 789-798. https://doi.org/10.1177/0956797613516471

Gross, J., Hudson, C., \& Price, D. (2009). The long-term costs of numeracy difficulties. London, UK: Every Child a Chance Trust. 
Haist, F., Wazny, J. H., Toomarian, E., \& Adamo, M. (2015). Development of brain systems for nonsymbolic numerosity and the relationship to formal math academic achievement. Human Brain Mapping, 36, 804-826. https://doi.org/10.1002/hbm.22666

Halberda, J., Mazzocco, M. M., \& Feigenson, L. (2008). Individual differences in non-verbal number acuity correlate with maths achievement. Nature, 455(7213), 665-668. https://doi.org/10.1038/nature07246

Harvey, B. M., Klein, B. P., Petridou, N., \& Dumoulin, S. O. (2013). Topographic representation of numerosity in the human parietal cortex. Science (New York, N.Y.), 341(6150), 1123-1126. https://doi.org/10.1126/science.1239052

He, L. X., Zhang, J., Zhou, T. G., \& Chen, L. (2009). Connectedness affects dot numerosity judgment: Implications for configural processing. Psychonomic Bulletin \& Review, 16, 509-517. https://doi.org/10.3758/PBR.16.3.509

Holloway, I. D. \& Ansari, D. (2009). Mapping numerical magnitudes onto symbols: The numerical distance effect and individual differences in children's mathematics achievement. Journal of Experimental Child Psychology, 103(1), 17-29. https://doi.org/10.1016/j.jecp.2008.04.001

Hyde, C. D. (2011). Two Systems of Non-Symbolic Numerical Cognition. Frontiers in Human Neuroscience, 5, 150. https://doi.org/10.3389/fnhum.2011.00150

Iuculano, T., Tang, J., Hall, C. W., \& Butterworth, B. (2008). Core information processing deficits in developmental dyscalculia and low numeracy. Developmental Science, 11, 669-680. https://doi.org/10.1111/j.1467-7687.2008.00716.x

Izard, V., Dehaene-Lambertz, G., \& Dehaene, S. (2008). Distinct cerebral pathways for object identity and number in human infants. PLoS Biology, 6, e11. https://doi.org/10.1371/journal.pbio.0060011

Izard, V., Sann, C., Spelke, E. S., \& Streri, A. (2009). Newborn infants perceive abstract numbers. Proceedings of the National Academy of Sciences of the United States of America, 106(25), 10382-10385. https://doi.org/10.1073/pnas.0812142106

Kadosh, R. C., Lammertyn, J., \& Izard, V. (2008). Are numbers special? An overview of chronometric, neuroimaging, developmental and comparative studies of magnitude representation. Progress in Neurobiology, 84(2), 132-147. https://doi.org/10.1016/j.pneurobio.2007.11.001

Kaufman, E. L., Lord, M. W., Reese, T. W, \& Volkmann, J. (1949). The discrimination of visual number. American Journal of Psychology, 62(4), 498-525. https://doi.org/ 10.2307/1418556

Kaufmann, L., Vogel, S., Starke, M., Kremser, C., Schocke, M., \& Wood, G. (2009). Developmental dyscalculia: compensatory mechanisms in left intraparietal regions in response to nonsymbolic magnitudes. Behavioral and Brain Functions, 5(1), 35. https://doi.org/10.1186/1744-9081-5-35

Kucian, K., Loenneker, T., Dietrich, T., Dosch, M., Martin, E., \& von Aster, M. (2006). Impaired neural networks for approximate calculation in dyscalculic children: a functional MRI study. Behavioral and Brain Functions, 2, 31. https://doi.org/10.1186/1744-9081-2-31

Kucian, K., Loenneker, T., Martin, E., \& von Aster, M. (2011). Nonsymbolic numerical distance effect in children with and without developmental dyscalculia: a parametric FMRI study.

Developmental Neuropsychology, 36(6), 741-762. https://doi.org/10.1080/87565641.2010.549867

Kucian, K., Ashkenazi, S. S., Hanggi, J., Rotzer, S., Jancke, L., Martin, E., \& von Aster, M. (2013). Developmental dyscalculia: a dysconnection syndrome? Brain Structure Function, 219(5), 17211733. https://doi.org/10.1007/s00429-013-0597-4

Kucian, K. \& von Aster, M. (2015). Developmental dyscalculia. European Journal of Pediatrics, 174, 1-13. https://doi.org/10.1007/s00431-014-2455-7

Landerl, K., Bevan, A., \& Butterworth, B. (2004). Developmental dyscalculia and basic numerical capacities: a study of 8-9-year-old students. Cognition, 93, 99-125. https://doi.org/10.1016/j.cognition.2003.11.004

Landerl, K., Fussenegger, B., Moll, K., \& Willburger, E. (2009). Dyslexia and dyscalculia: Two learning disorders with different cognitive profiles. Journal of Experimental Child Psychology, 103(3), 309-324. https://doi.org/10.1016/j.jecp.2009.03.006 
Libertus, M. E., \& Brannon, E. M. (2010). Stable individual differences in number discrimination in infancy. Developmental Science, 13(6), 900-906. https://doi.org/10.1111/j.1467-

7687.2009.00948.x

Libertus, M. E., Feigenson, L., \& Halberda, J. (2013). Is approximate number precision a stable predictor of math ability? Learning and Individual Differences, 25, 126-133. https://doi.org/10.1016/j.lindif.2013.02.001

Libertus, M. E., Odic, D., \& Halberda, J. (2012). Intuitive sense of number correlates with math scores on college-entrance examination. Acta Psychologica, 141(3), 373-379. https://doi.org/10.1016/j.actpsy.2012.09.009

Lipton, J. S., Spelke, E. S. (2004). Discrimination of large and small numerosities by human infants. Infancy, 5(3), 271-290. https://doi.org/10.1207/s15327078in0503_2

Lyons, I. M., Price, G. R., Vaessen, A., Blomert, L., \& Ansari, D. (2014). Numerical predictors of arithmetic success in grades 1-6. Developmental Science, 17, 714-726. https://doi.org/10.1111/desc. 12152

Mazzocco, M. M. M. (2005). Challenges in identifying target skills for math disability screening and intervention. Journal of Learning Disabilities, 38(4), 318-323. https://doi.org/10.1177/00222194050380040701

Mazzocco, M. M. M., Feigenson, L., \& Halberda, J. (2011). Preschoolers' precision of the approximate number system predicts later school mathematics performance. PLoS ONE, 6, Article e23749. https://doi.org/1371/journal.pone.0023749

McLean, J. F., and Hitch, G. J. (1999). Working memory impairments in children with specific arithmetic learning difficulties. Journal of Experimental Child Psychology, 74(3), 240-260. https://doi.org/10.1006/jecp.1999.2516

Meck, W. H., \& Church, R. M. (1983). A mode control model of counting and timing process. Journal of Experimental Psychology. Animal Behavior Processes, 9(3), 320-334.

Mussolin, C., De Volder, A., Grandin, C., Schlogel, X., Nassogne, MC., \& Noel, M. P. (2010). Neural correlates of symbolic number comparison in developmental dyscalculia. Journal of Cognitive Neuroscience, 22(5), 860-874. https://doi.org/10.1162/jocn.2009.21237

Nieder, A. (2013). Coding of abstract quantity by 'number neurons' of the primate brain. Journal of Comparative Physiology A, 199, 1-16. 10.1007/s00359-012-0763-9

Nieder, A. \& Dehaene, S. (2009). Representation of number in the brain. Annual Review of Neuroscience, 32, 185-208. https://doi.org/10.1146/annurev.neuro.051508.135550

Nieder, A., \& Miller, E. K. (2004). A parieto-frontal network for visual numerical information in the monkey. Proceedings of the National Academy of Sciences of the United States of America, 101(19), 7457-7462. https://doi.org/10.1073/pnas.0402239101

Novák, J. (2001). Barevná kalkulie. Brno: Psychodiagnostika.

Novák, J. (2002). Kalkulie IV. Brno: Psychodiagnostika.

Novák, J. (2004). Dyskalkulie: metodika rozvijeni základnich početních dovedností. Vyd. 3., zcela přeprac. Havlíčkův Brod: Tobiáš.

Olmstead, M., \& Kuhlmeier, V. (2015). Comparative cognition. London, UK: Cambridge University Press.

Olsson, L., Östergren, R., \& Träff, U. (2016). Developmental dyscalculia: A deficit in the approximate number system or an access deficit? Cognitive Development, 39, 154-167. https://doi.org/10.1016/j.cogdev.2016.04.006

Park, J., \& Brannon, E. M. (2014). Improving arithmetic performance with number sense training: an investigation of underlying mechanism. Cognition, 133(1), 188-200. https://doi.org/10.1016/j.cognition.2014.06.011

Park, J., Bermudez, V., Roberts, R. C., \& Brannon, E. M. (2016). Non-symbolic approximate arithmetic training improves math performance in preschoolers. Journal of Experimental Child Psychology, 152(12), 278-293. https://doi.org/10.1016/j.jecp.2016.07.011

Parsons, S., \& Bynner, J. (2005). Does numeracy matter more? London: National Research and Development Centre for Adult Literacy and Numeracy.

Piazza, M. (2010). Neurocognitive start-up tools for symbolic number representations. Trends in Cognitive Sciences, 14, 542-551. https://doi.org/10.1016/j.tics.2010.09.008 
Piazza, M., Izard, V., Pinel, P., Le Bihan, D., \& Dehaene, S. (2004). Tuning curves for approximate numerosity in the human intraparietal sulcus. Neuron, 44(3), 547-555. https://doi.org/10.1016/j.neuron.2004.10.014

Piazza, M., Facoetti, A., Trussardi, A. N., Berteletti, I., Conte, S., Lucangeli, D., Dehaene, S., \& Zorzi, M. (2010). Developmental trajectory of number acuity reveals a severe impairment in developmental dyscalculia. Cognition, 116(1), 33-41. https://doi.org/10.1016/j.cognition.2010.03.012

Piazza, M., Fumarola, A., Chinello, A., \& Melcher, D. (2011). Subitizing reflects visuo-spatial object individuation capacity. Cognition, 121, 147-153. https://doi.org/10.1016/j.cognition.2011.05.007

Piazza, M., Pinel, P., Le Bihan, D., \& Dehaene, S. (2007). A magnitude code common to numerosities and number symbols in human intraparietal cortex. Neuron, 53, 293-305. https://doi.org/10.1016/j.neuron.2006.11.022

Piazza, M., Facoetti, A., Trussardi, A. N., Berteletti, I., Conte, S., Lucangeli, D., Dehaene, S., \& Zorzi, M. (2010). Developmental trajectory of number acuity reveals a severe impairment in developmental dyscalculia. Cognition, 116(1), 33-41. https://doi.org/10.1016/j.cognition.2010.03.012

Pinel, P., Dehaene, S., Riviere, D., \& LeBihan, D. (2001). Modulation of parietal activation by semantic distance in a number comparison task. Neuroimage, 14(5), 1013-1026. https://doi.org/10.1006/nimg.2001.0913

Pinheiro-Chagas, P., Wood, G., Knops, A., Krinzinger, H., Lonnemann, J., Starling-Alves, I., \& Haase, V. G. (2014). In how many ways is the approximate number system associated with exact calculation? PLOS ONE, 9(11):e111155. https://doi.org/10.1371/journal.pone.0111155

Plassová, M., Tesař, M., Vavrečka, M., \& Valuchová, K. (2016). Approximate number system in children. In M. McGreevy \& R. Rita (Eds.), Proceedings of the 6th Biannual CER Comparative European Research Conference (pp. 182-187). London: Science.

Pražáková, K. (2017). Přesnost a rychlost ve vnímání množství u jedinců s dyskalkulií. Diplomová práce. Praha: Univerzita Karlova v Praze.

Price, G. R., Palmer, D., Battista, C., \& Ansari, D. (2012). Nonsymbolic numerical magnitude comparison: Reliability and validity of different task variants and outcome measures, and their relationship to arithmetic achievement in adults. Acta Psychologica, 17, 50-57. https://doi.org/10.1016/j.actpsy.2012.02.008

Purpura, D. J., \& Logan, J. A. R. (2015). The nonlinear relations of the approximate number system and mathematical language to early mathematics development. Developmental Psychology, 57(12), 1717-1724. https://doi.org/10.1037/dev0000055

Rotzer, S., Kucian, K., Martin, E., von Aster, M., Klaver, P., \& Loenneker, T. (2008). Optimized voxel-based morphometry in children with developmental dyscalculia. Neuroimage, 39, 417-422. https://doi.org/10.1016/j.neuroimage.2007.08.045

Rotzer, S., Loenneker, T., Kucian, K., Martin, E., Klaver, P., \& von Aster, M. (2009). Dysfunctional neural network of spatial working memory contributes to developmental dyscalculia. Neuropsychologia, 47(13), 2859-2865. https://doi.org/10.1016/j.neuropsychologia.2009.06.009

Rousselle, L., \& Noël, M. P. (2007). Basic numerical skills in children with mathematics learning disabilities: a comparison of symbolic vs non-symbolic number magnitude processing. Cognition, 102(3), 361-395. https://doi.org/10.1016/j.cognition.2006.01.005

Rykhlevskaia, E., Uddin, L. Q., Kondos, L., \& Menon, V. (2009). Neuroanatomical correlates of developmental dyscalculia: Combined evidence from morphometry and tractography. Frontiers in Human Neuroscience, 3, 51. https://doi.org/10.3389/neuro.09.051.2009

Samková, L. (2013). Využití programu GeoGebra při nácviku odhadů. Sborník 6. konference Užití počitačů ve výuce matematiky (323-336). České Budějovice: Jihočeská univerzita v Č. Budějovicích.

Sasanguie, D., Defever, E., Maertens, B., \& Reynvoet, B. (2014). The approximate number system is not predictive for symbolic number processing in kindergarteners. Quarterly Journal of Experimental Psychology, 67, 271-280. https://doi.org/10.1080/17470218.2013.803581 
Sasanguie, D., Göbel, S., \& Reynvoet, B. (2013). Left parietal TMS disturbs priming between symbolic and non-symbolic number representations. Neuropsychologia 51(8), 1528-1533. https://doi.org/10.1016/j.neuropsychologia.2013.05.001

Schneider, M. Schneider, M., Beeres, K., Coban, L., Merz, S., Schmidt, S. S., Stricker, J., \& De Smedt, B. (2016). Associations of non-symbolic and symbolic numerical magnitude processing with mathematical competence: a meta-analysis. Developmental Science, 20(3). https://doi.org/10.1111/desc.12372

Starr, A., Libertus, M. E., \& Brannon, E. M. (2013). Number sense in infancy predicts mathematical abilities in childhood. Proceedings of the National Academy of Sciences of the United States of America. https://doi.org/10.1073/pnas.1302751110

Sullivan, J., Frank, M. C., \& Barner, D. (2016). Intensive math training does not affect approximate number acuity: Evidence from a three-year longitudinal curriculum intervention. Journal of Numerical Cognition, 2(2), 57-76. https://doi.org/10.5964/jnc.v2i2.19.

Shalev, R.S., Manor, O., Kerem, B., Ayali, M., Badichi, N., Friedlander, Y., \& Gross-Tsur, V. (2001). Developmental dyscalculia is a familial learning disability. Journal of Learn Disabilities, 34 (1), 59-65. https://doi.org/10.1177/002221940103400105

Schleger, F., Landerl, K., Muenssinger, J., Draganova, R., Reinl, M., Kiefer-Schmidt, I., Weiss, M., Wacker-Gussmann, A., Huotilaine, M., \& Preissl, H. (2014). Magnetoencephalographic signatures of numerosity discrimination in fetuses and neonates. Developmental Neuropsychology, 39(4), 316-329. https://doi.org/10.1080/87565641.2014.914212.

Schwenk, C., Sasanguie, D., Kuhn, J. T., Kempe, S., Doebler, P., \& Holling, H. (2017). (Non-) symbolic magnitude processing in children with mathematical difficulties: A meta-analysis. Research in Developmental Disabilities, 64, 152-167. https://doi.org/10.1016/j.ridd.2017.03.003

Soto-Calvo, E., Simmons, F. R., Willis, C., \& Adams, A. M. (2015). Identifying the cognitive predictors of early counting and calculation skills: Evidence from a longitudinal study. Journal of Experimental Child Psychology, 140, 16-37. https://doi.org/10.1016/j.jecp.2015.06.011

Sousa, D. (2010). Mind, brain, and education: Neuroscience implications for the classroom. Bloomington, IN: Solution Tree.

Taves, E. H. (1941). Two mechanisms for the perception of visual numerousness. Archives of Psychology, 265(47).

Traspe, P., \& Skalková, I. (2013). DISMAS : Diagnostika struktury matematických schopností. Praha: Národní ústav pro vzdělávání.

Ven, F. van der, Takashima, A., Segers, P. C. J., Fernandez, G. S. E., Verhoeven, L. T. W. (2016). Non-symbolic and symbolic notations in simple arithmetic differentially involve intraparietal sulcus and angular gyrus activity. Brain Research, 1643, 91 - 102. https://doi.org/10.1016/j.brainres.2016.04.050

Von Aster, M., \& Shalev, R. (2007). Number development and developmental dyscalculia. Developmental Medicine \& Child Neurology, 49, 868-873. https://doi.org/10.1111/j.14698749.2007.00868.x

von Aster, M. G. \& Weinholdová, M. (2008). ZAREKI: Neuropsychologická batéria testov na spracovávanie čisiel a počitanie u detí. Bratislava, Brno: Psychodiagnostika.

Xu, F., \& Spelke, E. S. (2000). Large number discrimination in 6-month-old infants. Cognition, 74, B1-B11. https://www.harvardlds.org/wp-content/uploads/2017/01/xu2000b-1.pdf 


\section{Údaje o autorech}

Mgr. Vendula Šamajová se v rámci doktorského studia na Katedře psychologie Fakulty sociálních studií Masarykovy univerzity $v$ Brně zaměřuje zejména na problematiku matematických schopností a diagnostiku dyskalkulie, zároveň pracuje jako školní psycholožka na základní škole.

\section{Kontaktní údaje:}

Adresa: Fakulta sociálních studií Masarykovy univerzity v Brně, Joštova 10, Brno Email: samajova.vendu@ seznam.cz

Mgr. Hynek Cígler, Ph.D., působí na Katedře psychologie \& Institutu pro výzkum dětí, mládeže a rodiny, Fakulta sociálních studií Masarykovy univerzity v Brně.

\section{Kontaktní údaje:}

Adresa: Fakulta sociálních studií Masarykovy univerzity v Brně, Joštova 10, Brno

Email: hynek.cigler@mail.muni.cz

Šamajová, V., \& Cígler, H. (2020). Potenciál měření nesymbolických početních schopností pro časnou diagnostiku dyskalkulie. E-psychologie, 14(2), 1-23. https://doi.org/10.29364/epsy.369 